\title{
УДК 331:1
}

Ощчипок I. M., him1960@ukr.net, ORCID ID:0000-0002-5427-3376,

Researcher ID: F-4641-2019,

д.т.н., проф., завідувач кафедри харчових технологій, Львівський торговельно-економічний університет, м. Львів

\section{КОМПЕТЕНТНІСНИЙ ПІДХІД В СТИМУЛЮВАННІ ПРАЦІВНИКІВ ЗА ІННОВАЦІЙНУ ДІЯЛЬНІСТЬ}

\begin{abstract}
Анотація. У статті розглянуті концептуальні підходи до сутності стимулювання інноваційної активності працівників від їх творчої діяльності, спрямовані на удосконалення функціональної, організаційної, адміністративної структури підприємств, організацій і установ з метою підвищення ефективності виробничо-господарської, навчально-наукової діяльності. Описано інформаційні й управлінські інновації. Показано різні підходи до інновачійної активності для впровадження досконаліших форм організаџії праці й управління виробниитвом, забезпеченням трудової активності, пов'язаної з реалізацією набутих знань, творчих здібностей, професіоналізму працівників. За умов формування конкурентного середовища саме знання, творчі здібності, розвинуті інформаційні потреби, здатність до навчання та перенавчання, мотивація саморозвитку визначають можливість інноваційної активності працівників, врешті-решт - їх конкурентні переваги на ринку праці. Наведено чинники впливу на інноваційну активність працівників, яка пов'язана з неоднаковістю у різних людей, оскільки їм притаманні різні рівні мотиваціі, різні відмінності творчих та інтелектуальних здібностей, різна швидкість розумових процесів. Навчання $і$ мотивація працівників спрямовані на формування активного $i$ кваліфікованого персоналу, який поряд з матеріальною базою і організацією робіт є одним з основних чинників якості праці. Розглянуто компетентність як сукупність особистісних здібностей, знання та вміння працівни$\kappa$, щзо дозволяє йому вирішити певну групу професійних проблем. Підхід, базований на компетентності, активно використовується у підборі, відборі персоналу, оцінці та стимулюванні. Працівники, які мають високу кваліфікацію, досягають абсолютно різних результатів завдяки різним особистим якостям, природним здібностям, досвіду роботи, трудовій етиці тощо. Ці відмінності мають бути відображені системою оплати праці. Розроблено систему стимулювання праці з урахуванням компетенцій із різними типами заохочень. Запропоновано класифікацію компетентностей, на підставі яких встановлені найбільш важливі для розвитку та застосування працівниками під час професійної діяльності.
\end{abstract}

Ключові слова: компетенція, заохочення, стимулювання, оплата, інновації.

Oshchypok I. M., him1960@ukr.net, ORCID ID:0000-0002-5427-3376,

Researcher ID: F-4641-2019, Doctor of Engineering, Professor, Head of the Department of Food Technologies, Lviv University of Trade and Economics, Lviv

\section{COMPETENCE APPROACH IN ENCOURAGING EMPLOYEES FOR INNOVATIVE ACTIVITY}

\begin{abstract}
The article considers conceptual approaches to the essence of encouraging innovativeness of employees from their creative activities aimed at improving the functional, organizational, administrative structure of enterprises, organizations and institutions in order to increase the efficiency of production, economic, educational and scientific activities. The information and managerial innovations are described. Different approaches to innovative activity for introduction of more perfect forms of the organization of work and management of production, maintenance of labor activity connected with application of the acquired knowledge, creative abilities, professionalism of workers are shown. Under conditions of a competitive environment development, exactly knowledge, creative abilities, developed information needs, ability to learn and retrain, motivation of self-development determine the possibility of innovative activity of employees, ultimately - their competitive advantages in the labor market. The factors influencing the innovative activity of employees, which can not be the same for different people, because different people have different levels of motivation, creative and intellectual abilities, speed of mental processes, are revealed. Training and motivating of employees are aimed at forming an active and qualified staff, which, along with the material base and organization of activities is one of the main factors of the work quality. Competence is considered as a set of personal abilities, knowledge and skills of the employee, which allows him to solve a certain group of professional problems. The competence-based approach is actively used in recruitment, selection, evaluation and promotion of staff.
\end{abstract}


Highly qualified employees achieve completely different results of their work due to different personal qualities, natural abilities, work experience, ethics, etc. These differences should be reflected in the wage system. According to the study results a system of work incentives has been developed, taking into account competencies with different types of labor encouraging. The classification of competences is proposed on the basis of which the most important for development and application by staff during professional activities are determined.

Keywords: competence, encouragement, incentives, payment, innovation.

JEL Classification: J31, J33, M51, M52, O15

DOI: https://doi.org/10.36477/2522-1205-2020-61-06

Постановка проблеми. Впровадження компетентнісного підходу в систему стимулювання праці визначає попит на відповідну корекцію в методах класифікації, оцінки персоналу та винагороди [3]. Організація вдосконалює свій бізнес і продуктивність через розвиток персоналу. Ефективність праці може бути збільшена завдяки унікальним індивідуальним здібностям людей, їх знанням, навичкам, досвіду та особистісним характеристикам, які проявляються через їхню трудову поведінку та орієнтацію на зацікавленість та творчість.

Об’єктивна необхідність посилення інноваційного характеру виробничої діяльності в нових умовах господарювання обумовлює особливу значущість проблеми активізації творчої праці працівників у вирішенні питань інноваційного розвитку підприємств сфери послуг. Таким чином, для активізації інноваційної діяльності необхідне формування і запровадження дієвої системи стимулювання праці суб'єктів інноваційного процесу, яка повинна відповідати цілям роботодавців та сприяти вирішенню основних його завдань. Отже, в сучасних умовах особливої уваги набувають проблеми відновлення винахідницької та раціоналізаторської діяльності на підприємствах і в установах, навчальних закладах, створення відповідних стимулів для розвитку інноваційної праці.

Аналіз останніх досліджень і публікацій. Проблема стимулювання інноваційної діяльності підприємств доволі широко розглядається в роботах О. I. Амоші, В. П. Антонюка, В. М. Геєця та інших $[1-2 ; 5]$. Також значний внесок у вивчення питань розвитку інноваційної праці в системі координат знань здійснили Д. П. Богиня, А. М. Колот, С. В. Стаценко $[3,4 ; 6,7,10]$.

При характеристиці інноваційної діяльності на рівні підприємства використовується поняття "інноваційна активність підприємств”, введене Собко О. М. Щодо категорії “інноваційна активність працівників”, то серед фахівців немає єдиної точки зору. Можна виділити декілька підходів, а саме:

- розуміння інноваційної активності як прояву творчості у трудовому процесі (Друкер П., Слезингер Г., Твисс Б., Самуельсон П., Хекхаузен Х.);

- сприйняття інноваційної активності як функції суб' єктів підприємницької діяльності щодо створення нововведень у будь-якій сфері (Мочерний С. В.);
- визначення інноваційної активності як однієї $з$ важливих складових характеристик трудового потенціалу або людського потенціалу загалом, реалізація яких дає змогу створювати різноманітні нововведення в процесі трудової діяльності, здійснювати інноваційну працю (Грішнова О. А., Лісогор Л. С., Семикіна М. В., Шаульська Л. В.).

Серед недоліків першого підходу $є$ те, що він обмежується мікроекономічним рівнем та не враховує вплив зовнішньоекономічного середовища, коливань ринкового попиту, необхідність державного регулювання інноваційної активності найманих працівників.

Незважаючи на значну кількість робіт із проблем інноваційної діяльності підприємств, мотивації та стимулювання інноваційної праці, існуюча складна ситуація в інноваційній діяльності вимагає подальшого розвитку та поглиблення досліджень у цьому напрямі. Здійснення інноваційних перетворень на підприємствах диктує персоналу активне включення до цього процесу, що потребує розробки відповідних заходів із забезпечення у трудових колективах підвищення престижу працівників-інноваторів.

Постановка завдання. Визначення концептуальних підходів до сутності стимулювання інноваційної активності працівників від їх винахідницької роботи розглянемо як можливість забезпечення організаційних заходів, спрямованих на удосконалення функціональної, ділової, адміністративної структури 3 метою підвищення ефективності виробничо-господарської, навчально-наукової діяльності підприємств, організацій і установ, розробку та впровадження результатів виробничого функціонування.

Інформаційні інновації, пов'язані 3 використанням сучасних цифрових технологій, забезпечують господарську діяльність 3 метою економії часу на отримання необхідної інформації, здешевлення інформаційних ресурсів та розробки власної інформаційної бази.

Управлінські інновації спрямовані на створення та використання прогресивних сучасних форм організації та управління персоналом на виробництві 3 метою підвищення продуктивності праці.

Інновації обумовлені ринковою необхідністю створення та підтримки активної збутової політики підприємства, яка б забезпечувала вчасний збут виробленої продукції або послуг 3 необхідними обсягами з метою отримання прибутку. 
На нашу думку, всі перераховані види інновацій необхідно розглядати в поєднанні.

Виклад основного матеріалу дослідження. Визначившись із сутністю та видами інновацій, слід зазначити, що рівень впровадження інновацій в Україні надзвичайно низький. Наслідком цього є: нестача коштів для розвитку інноваційної діяльності; недостатня фінансова підтримка з боку держави; значний обсяг витрат на нововведення; недосконалість законодавчої бази інноваційного розвитку; високий економічний ризик впровадження інновацій; тривалий термін окупності; нестача кваліфікованих кадрів, здатних сприймати інновації; низький платоспроможний попит на нову продукцію; гальмування розвитку високотехнологічних галузей промисловості; зниження рівня конкурентоспроможності економіки України.

3 метою уникнення цих наслідків необхідно запровадити комплексну систему заходів, спрямованих на стимулювання підвищення інноваційної активності як підприємств, так і працівників. Що стосується працюючих, то необхідно основну увагу приділити їх творчій участі у реалізації стратегічних задач інноваційного розвитку виробництва, спонукання до інноваційної праці та інноваційної активності.

Сучасний підхід до інноваційної активності можна розглянути як цілеспрямовану діяльність суб'єктів господарювання щодо конструювання, створення, освоєння та виробництва якісно нових видів технологій, техніки, предметів праці, об'єктів інтелектуальної власності, а також впровадження досконаліших форм організації праці й управління виробництвом.
Інший підхід розглядає трудову діяльність найманих працівників 3 позиції їх ідей. Уявлення про якісну та кількісну структуру трудового потенціалу, умов його реалізації на всіх рівнях в ринковому середовищі, у здатності найманих працівників до генерації нових ідей, розробки нововведень у відповідній сфері їх діяльності, прояву творчості становить важливий компонент трудового потенціалу колективу, що створює умови для ефективної праці. При цьому інноваційну активність слід розглядати як прояв трудової активності, пов'язаний із реалізацією набутих знань, творчих здібностей, професіоналізму. Підкреслимо, що за умов формування конкурентного середовища саме знання, творчі здібності, розвинуті інформаційні потреби, здатність до навчання та перенавчання, мотивація саморозвитку визначають можливість інноваційної активності працівників, врешті-решт їх конкурентні переваги на ринку праці.

Виокремимо інноваційну складову в структурі трудового потенціалу окремого працівника, колективу працівників, розуміючи під нею здатність до розробки і впровадження інновацій, прояву творчості у праці незалежно від сфери трудової діяльності. Цей підхід слід вважати більш доцільним і обгрунтованим, але детальної уваги вимагають визначеність сфери інноваційної діяльності та наявність ऑї цілеспрямованості.

Інноваційна активність працівників залежить від наступних складових трудового потенціалу (рис. 1).

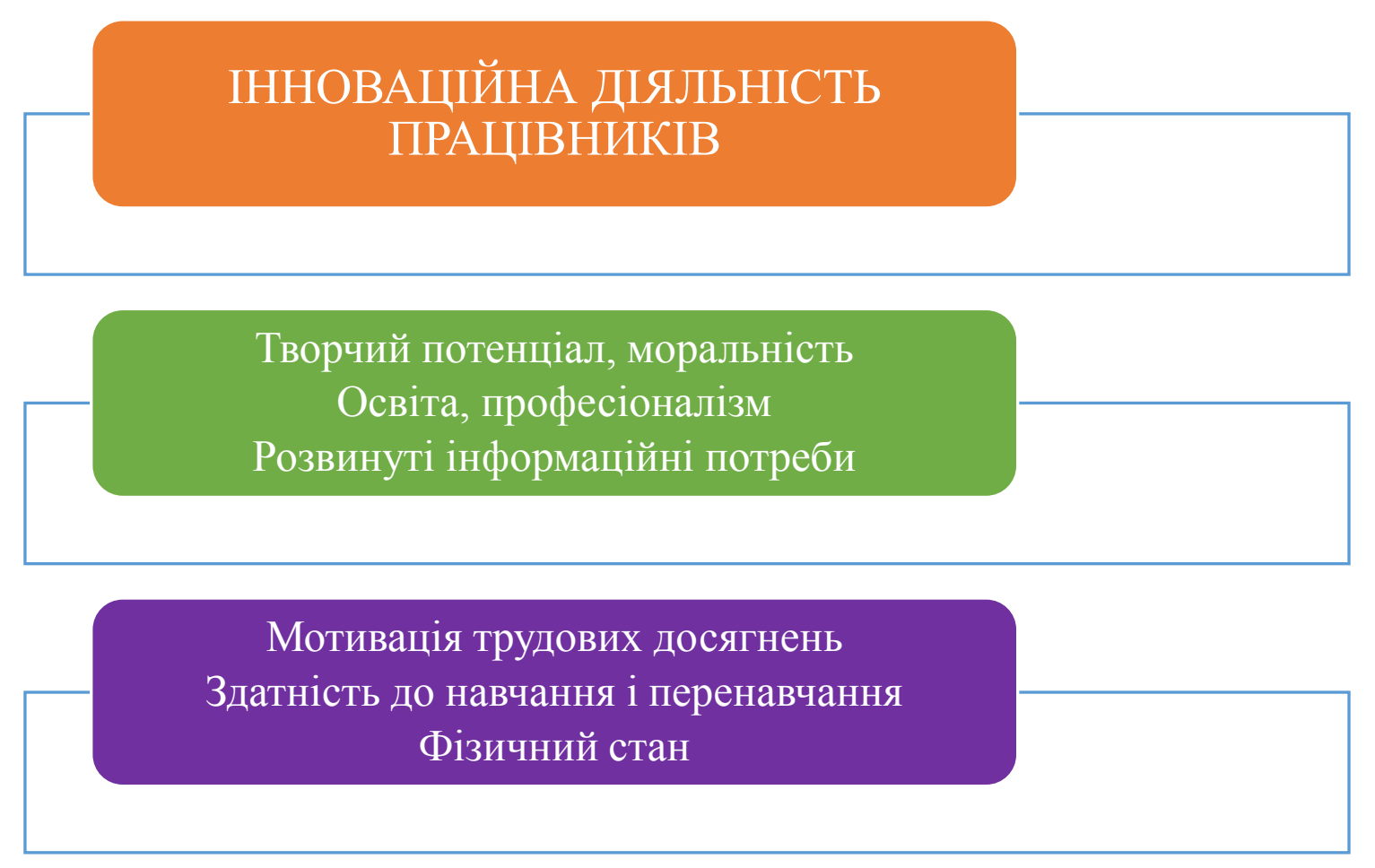

Рис. 1. Чинники впливу на інноваційну активність працівників 
Інноваційна активність працівників виступає внутрішнім чинником, але іiі формування та прояв знаходиться в значній мірі під впливом зовнішнього середовища. Тому завжди існує ймовірність, що ці обидва чинники діють незалежно один від одного або всупереч один одному. Специфіка інноваційної активності пов'язана 3 неоднаковістю у різних людей, оскільки їм притаманні різні рівні мотивації, різні відмінності творчих та інтелектуальних здібностей, різна швидкість розумових процесів. Тому інноваційна активність важко піддається регламентації.

Специфічні особливості інноваційної активності працівників полягають у наступному: така активність вимагає творчих та інтелектуальних здібностей і не може бути притаманна усім працівникам в однаковій мірі; час на розробку інновацій не піддається регламентації, тому не може мати чітко визначених меж інтенсивності праці.

Суб'єкт інноваційної активності сам визначає складність завдань, кінцевий результат та ефект інноваційної активності, який слабо прогнозується. Вдосконалення якості результату такої активності не має меж. При цьому ризиковий характер, непередбачуваність побічних ефектів та кінцевих результатів інноваційної діяльності вносить психологічне напруження в діяльність новаторів, що відображає тенденцію до спаду інноваційної активності.

Необхідними умовами розвитку інноваційної діяльності $\epsilon$ розвиток людських ресурсів, формування нового трудового менталітету в умовах розробки і впровадження інновацій, освоєння професійних знань, нового відношення до виробничої діяльності. Сучасні ділові тенденції, пов'язані 3 науково-технічним прогресом і посиленням конкуренції, призводять до підвищення вимог до професіоналізму працівників, їх інтелектуального рівня та якості праці. Для пришвидшення інноваційної активності велике значення мають інвестування в персонал, його навчання, матеріальне стимулювання за якісні показники праці, а також створення сприятливих умов праці. Навчання і мотивація працівників спрямовані на формування активного i кваліфікованого персоналу, який поряд 3 матеріальною базою і організацією робіт $є$ одним із основних чинників якості праці. Тому для досягнення ефективної діяльності підприємства необхідно запровадити процес постійного підвищення кваліфікації і перепідготовки працівників за всіма необхідними напрямами, у тому числі - 3 управління якістю продукції, вивчення нових властивостей інноваційної продукції, методів забезпечення iї використання та надійності.

Ми розглянемо компетентність як сукупність особистісних здібностей, знання та вміння працівника, що дозволяють йому вирішити певну групу професійних проблем. Підхід, базований на компетентності, активно використовується у підборі, відборі персоналу, оцінці та стимулюванні. Також компетентність може визначатися як формально встановлені вимоги до особистісних, професійних та інших якостей службовців підприємства (певної його частини). Ця формула сприятиме висуванню деяких вимог до оцінки якостей персоналу.

Перш ніж підприємство може створити та ініціювати здійснення заходів щодо ідентифікації, формування, розвитку або стимулювання певних компетенцій у своєму штаті працівників, дуже багато роботи повинно проводитися для вивчення вимог щодо діяльності, яка грунтується на компетентності, їх групуванні та визначенні співвідношень між досягненням мети, успішної роботи та рівнем компетентності. Ця робота має виконуватися менеджерами в тісній співпраці з виконавцями.

Визначення компетенції можна проводити за такими ознаками:

1) компетентність - це потенціал людини, яка має необхідні внутрішні якості;

2) компетентність проявляється як конкретний результат професійної діяльності (який спостерігається і вимірюється).

Ці ознаки мають важливе значення з точки зору визначення компетенцій персоналу та оцінки в будь-якій організації, а також вибір конкретних заходів, які слід застосовувати з метою розвитку компетенцій для стимулювання винагороди за працю.

Компетентнісний підхід до винагороди за виконану роботу не тільки логічно аргументований, але максимально наближує досягнення соціальної справедливості для будь-яких випадків, де мають місце умови невід'ємного характеру, непрозорого ринку праці. Це може бути досягнуто завдяки тому, що оцінка результатів діяльності працівника через компетентність враховує як поточний, так і попередній результат роботи особи. Минулі зусилля дозволили особистості досягти необхідного рівня компетенції, якими вона зараз володіє, в той час як поточні зусилля створюють теперішні результати виконання поставлених завдань.

Працівники, які мають високу кваліфікацію, можуть досягти абсолютно різних результатів завдяки різним особистим якостям, природним здібностям, досвіду роботи, трудовій етиці тощо. Ці відмінності мають бути відображені системою оплати праці. Отже, структура заробітної плати повинна включати гарантовану частину, визначену законодавством про працю, та стимулюючу частину, яка враховує показники індивідуальної та загальної ефективності роботи. Ця стимулююча частина винагороди, у свою чергу, повинна включати заслужену частину, отриману завдяки попередньому досвіду та з урахуванням результату, який має форму досягнутого рівня компетентності, і теперішню діяльність застосування компетенцій у повсякденній роботі, яка є формою отримання конкретних результатів для досягнення мети та вимог підприємства.

Система стимулювання праці 3 урахуванням компетенцій повинна включати різні типи заохочень (рис. 2). 


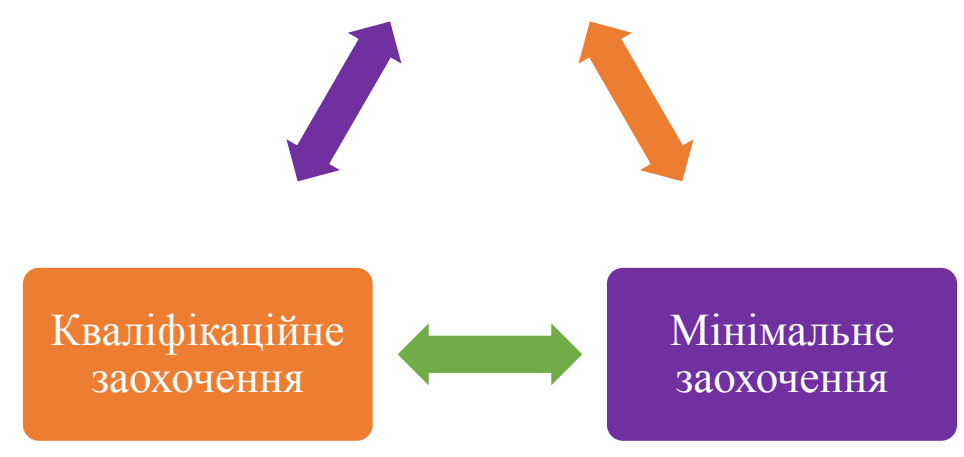

Рис. 2. Система стимулювання праці з урахуванням компетенцій

Стимули за отримання успішного досягнення (винаходу) збільшують професійний потенціал компетентності працівника, необхідний для досягнення і стимулювання його ділової активності i праці в майбутньому. Цей розмір має бути пропорційним успіху досягненої мети і практично необмеженим, хоча можна вважати, що отримання такої винагороди у розмірі, що перевищує 100-120 \% від заробітної плати, можливе у разі щомісячних виплат. Виплати, які проводяться 1-2 рази на рік, для заохочення можуть становити 400-600 \% від щомісячної зарплати. Вважаємо за доцільне застосовувати частіше менші заохочення завдяки наявності деяких зручностей для руху грошових потоків підприємства та кращої здатності впливати і коригувати трудову поведінку. Щорічні платежі можуть i не мати значного впливу на трудову поведінку працівника, навіть якщо надаються вагомі суми. Крім цього, інтервал можливої корекції в такому випадку також може бути впродовж року, що $є$ неприйнятним для сьогоденної стрімкої зміни ділового середовища.

Розгляд компетенцій під час відбору матеріальних стимулів для персоналу повинен здійснюватися 3 дотриманням принципу паритету між розміром оплати праці та особистим внеском працівника у кінцевий результат діяльності підприємства або підрозділу, а також вимог щодо соціальної справедливості заробітної плати та передбачати диференціацію доходів. Належні оцінки компетенції допомагають працівникові покращувати та вдосконалювати свої професійні знання для підвищення продуктивності та якості роботи. Тому необхідно виділити особистісні та професійні здібності та вміння, що можна розглядати як компетенцію при тих чи інших умовах, необхідних для конкретної професії або справи. Існує багато різних способів класифікації професійних компетенцій. Класифікацію компетентностей запропонуємо проводити на підставі, яка $є$ найбільш важливою для розвитку та застосування працівниками на виробництві (рис. 3).

Недовершені - здатності людини дозволяють використовувати їх у професійній діяльності, вони можуть бути достатньо сформованими і готовими у тих, хто в процесі своєї діяльності їх набув, або ж недостатніми.

Джерело набування або спосіб формування виникає через освіту або за допомогою самоосвіти; набуті разом 3 професійним або загальним досвідом.

Масштабні знання - універсальні, які можна застосовувати для будь-якого виду робіт або навіть інших видів діяльності людини; необхідний професіоналізм для якісного виконання роботи в певній професійній галузі; спеціальні, що застосовуються для певної роботи чи операцій на підприємстві.

Кваліфікаційне заохочення вимагає офіційного доведення досягнення певного кваліфікаційного рівня або, іншими словами, здобутку, зокрема загальних компетенцій. Це можна проілюструвати оплатою праці за стаж (або тривалого періоду роботи в межах того ж самого підприємства), оцінку або рейтинг для наукових працівників та викладачів університетів, отримання ступеня, володіння мовами тощо. Усі вони можуть бути засвідченими документами, але не всі вони доводять необхідність застосування цих навичок безпосередньо в діяльності протягом періоду, за який потрібно платити, за виконану роботу. Тим не менше таких заохочень не уникнути, інакше штат втратить стимули для професійного зростання та вдосконалення, оскільки підвищення кваліфікації забирає час і сили від досягнення необхідного (i, безумовно, винагородженого) результату. До того ж, такі заохочення повинні бути призначені працівникові постійно або принаймні протягом тривалого періоду порівняно 3 періодом, необхідним для досягнення професійного рівня (принаймні протягом декількох років), інакше будуть проявлятися дрібні i дуже слабкі 
невдоволення. 3 іншого боку, це не заважає роботодавцю вимагати регулярного підвищення i підтвердження свого професійного рівня штатними працівниками, наприклад завдяки постійному проміжному контролю, затвердженому і встановленому в документації підприємства. Зазвичай отримання нових навичок або компетенцій, особливо підтверджених офіційними сертифікатами або дипломами, вимагає значних зусиль від людини, іноді навіть вкладення особистих коштів, коли працівник вважає, що їх варто витратити на навчання, і він погодиться лише у тому випадку, якщо буде впевнений у винагороді за це. Ось чому така винагорода може коливатися в дуже широких діапазонах залежно від характеру отриманого рівня або досягнення (витрачений час і кошти, затрачені зусилля), а також переваг, які отримає роботодавець для розширення діапазону виробничих функцій працівника.

Мінімальне заохочення застосовується як одноразова винагорода за успіх працівника в нетиповій і необгрунтованій ситуації, з точки зору умов компетентнісного підходу, навіть якщо він досягнутий завдяки якомусь сприятливому поєднанню зовнішніх обставин, які можна назвати “інсультом удачі”. Прикладом такої ситуації може бути отримання високих результатів роботи не через професіоналізм та зусилля працівників, але через раптові сприятливі зміни умов діяльності або рівень компетенції, якого легко можна досягнути і який потребує мінімум специфічних навичок: небезпечні або віддалені географічно місця чи суворі природні умови. У такому випадку очікується мінімальне заохочення, оскільки такі результати не стимулюють працівників до ефективної діяльності. Розмір заохочення тоді може становити приблизно 6-12 \% від середньомісячної зарплати. В таких випадках залежно від конкретних особливостей підприємства та сфери ділової діяльності ці цифри можуть значно змінюватися.

Рівні компетентності, що вимагають значних зусиль працівника (наприклад, отримання наукового ступеня, патенту на винахід), повинні бути винагороджені більш суттєво. Важливий момент - іноді роботодавець нічого не отримує від того, що його працівники мають такі визнані компетенції. У цьому випадку наявність або відсутність заохочень для них повинна бути чітко зазначена в описі вакансії та не може бути змінена згодом. I все ж у деяких випадках роботодавець повинен оплачувати за наявні компетенції, якими володіють його працівники та які зараз не застосовуються, заради ймовірної майбутньої потреби у них, спричинених змінами в технології або політиці підприємства. Тим не менше загальна сума таких платежів “на потенціал”, навіть якщо вони не використовуються в даний час, не повинна перевищувати 50-70\% щомісячної зарплати. Винагорода, наприклад заохочення за роботу на підприємстві, може збільшуватися на 3-7 \% в середньому за кожні 5 років. Отже, беручи до уваги ступінь важливості компетентностей працівника та їх використання в роботі, що необхідно для покращення системи оплати праці, це можна вирішити лише засобами ретельного аналізу конкретної ситуації на даному підприємстві. Хоча при впровадженні такої системи заохочення спостерігаються певні труднощі.

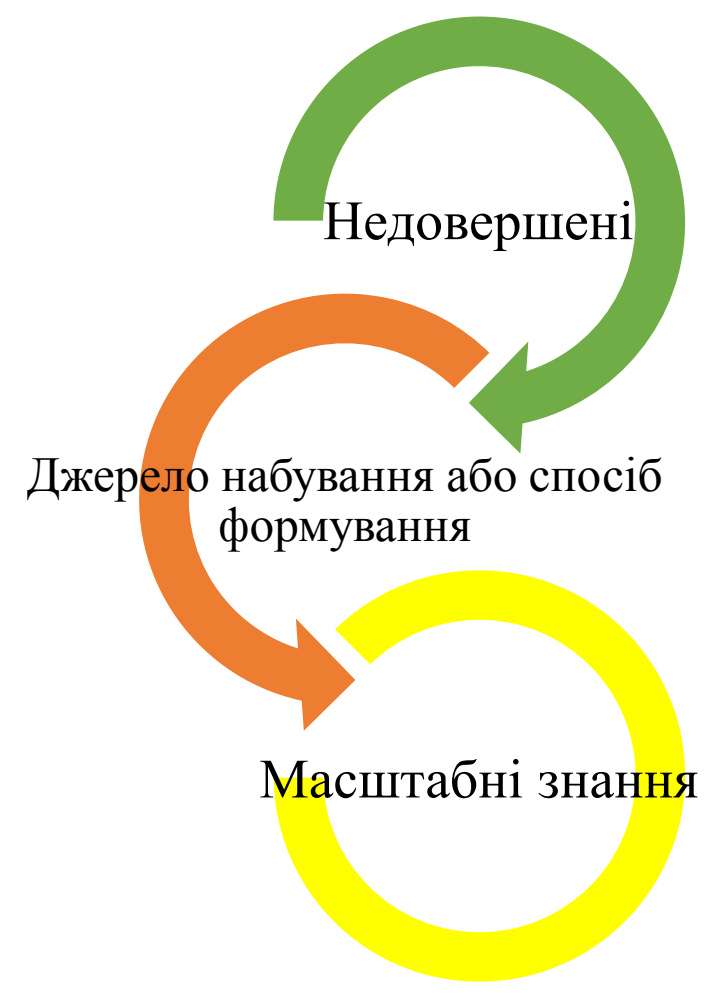

Рис. 3. Класифікація компетентностей 
Висновки i перспективи подальших досліджень у даному напрямі. Стимулювання інноваційної активності є дуже складним процесом у силу специфіки цього виду діяльності. Специфіка полягає в тому, що, по-перше, необхідно добитися підвищення розумової активності, стимулювати пошук нестандартних рішень, створити і підтримувати атмосферу творчості. По-друге, сама по собі інноваційна діяльність в ринкових умовах не виступає кінцевим результатом, а тільки ії комерційний результат, якого взагалі може і не бути. В той же час головною передумовою впровадження результатів наукових досліджень та їх комерціалізації $\epsilon$ сприятливе інноваційне середовище та розвиненість реального сектора економіки. Таким чином, під стимулюванням інноваційної діяльності підприємств, установ і організацій розуміємо процес зовнішнього впливу на інтереси роботодавців, працівників, суб'єктів фінансування інновацій для появи в них спонукального мотиву в здійсненні інноваційної діяльності та підвищенні ії ефективності. Основними напрямками стимулювання інноваційної активності вважаємо наступні: пошук, відбір та підготовка висококваліфікованих фахівців; формування позитивного сприйняття інновацій; привабливість нововведень для творчих людей; активна участь у розробці і впровадженні інновацій; формування іміджу організації, яка активно підтримує інновації, цінує творчих людей; формування колективу творчих працівників; накопичення і розвиток інноваційного потенціалу.

Концептуальні підходи до визначення сутності системи стимулювання інноваційної активності працівників слід розвивати в наступних напрямках. Перший підхід полягає у впровадженні нових або вдосконалених рішень у розробку машин і обладнання, продуктів із заданими властивостями, сучасних організаційних форм, постачання та збуту продукції. Другий - у процесі впровадження суттєво нових виробів та технологій, елементів і принципів замість існуючих.

Під сутністю поняття “інноваційна праця" розуміємо трудову діяльність, для якої характерна висока частка знаннєвої, інтелектуальної, творчої компоненти, яка здатна задовольнити суспільні потреби з найбільшим корисним ефектом.

\section{ЛІТЕРАТУРА}

1. Амоша О. I. Механізм забезпечення активізації інноваційної діяльності в Україні / O. I. Амоша // Социально-экономические аспекты промышленной политики: сб. науч. тр. / НАН Украины Ин-т экономики пром-сти; редкол.: Амоша А. И. (отв. ред.) и др. - Донецк, 2006. - С. 5-16.

2. Антонюк В. Кадри для інноваційної діяльності: проблеми формування та використання / В. Антонюк // Україна: аспекти праці. - 2007. № 5. - C. 42-47.

3. Богиня Д. П. Інноваційна праця в умовах трансформації економіки / Д. П. Богиня // Вісник Донбаської державної машинобудівної академії : зб. наук. праць. - 2008. - №2 (12). - С. 40-43.
4. Геєць В. М. Інноваційні перспективи України / В. М. Геєць, В. П. Семиноженко. - Х. : Константа, 2006. -272 c.

5. Колот А. Інноваційна праця та інтелектуальний капітал у системі факторів формування економіки знань / А. Колот // Україна: аспекти праці. 2007. - № 4. - C. 4-9.

6. Колот А. М. Інноваційно-інтелектуальні чинники розвитку вищої освіти як провідного інституту економіки знань / Колот А. М. // Стратегія розвитку України: економіка, соціологія, право. Вип. 1-2. - К. : НАУ, 2008. - С. 502-507.

7. Кравченко О. О. Психологічні аспекти управління персоналом / О. О. Кравченко, С. В. Кикоть // Молодий вчений. - 2016. - № 3. С. 101-103.

8. Руденко М. В. Навчання персоналу як ресурсна складова управління підприємством / М. В. Руденко // Вісник Хмельницького національного університету. Економічні науки. - Хмельницький : Хмельницький національний університет, 2016. - № 2. - Т. 1. - С. 33-38 [Електронний pecypc]. - Режим доступу : http://journals.khnu.km.ua/vestnik/pdf/ekon/pdfbase/20 16/VKNU-ES-2016-N2-Volume1_234.pdf\#page=33.

9. Стаценко Є. В. Адаптація міжнародних нематеріальних методів мотивації персоналу до сучасної системи стимулювання праці в Україні / Є. В. Стаценко, Ю. В. Лобода // Економіка та управління. - 2011. - С. 11-13.

10. Теория приобретенных потребностей Д. МакКлеланда // Энциклопедия менеджмента. 2013 [Электронный ресурс]. - Режим доступа : http://www.pragmatist.ru/motivaciya-

truda/teoriyapriobretennyx-potrebnostej-dmakklellanda.html.

11. 123456789/10824/1/.

https://dspace.nuph.edu.ua/bitstream/

12. http://vlp.com.ua/files/84_0.pdf дата звернення 09.10.2020.

\section{REFERENCES}

1. Amosha, O. I. (2006), Mekhanizm zabezpechennya aktyvizatsiyi innovatsiynoyi diyal'nosti v Ukrayini, Sotsyal'no-ékonomycheskye aspekty promyshlennoy polytyky: sb. nauch. tr.; NAN Ukrayny Yn-t ekonomyky prom-sty; redkol.: Amosha A. Y. (otv. red.) i dr., Donetsk, s. 5-16.

2. Antonyuk V. (2007), Kadry dlya innovatsiynoyi diyal'nosti: problemy formuvannya ta vykorystannya, Ukrayina: aspekty pratsi, №5, s. 42-47.

3. Bohynya, D. P. (2008), Innovatsiyna pratsya v umovakh transformatsiyi ekonomiky, Visnyk Donbas'koyi derzhavnoyi mashynobudivnoyi akademiyi: zb. nauk. prats', №2 (12), s. 40-43.

4. Heyets', V. M. and Semynozhenko, V. P. (2006), Innovatsiyni perspektyvy Ukrayiny, Konstanta, Kh., 272 s.

5. Kolot A. (2007), Innovatsiyna pratsya ta intelektual'nyy kapital u systemi faktoriv formuvannya ekonomiky znan', Ukrayina: aspekty pratsi, № 4, s. 4-9. 
Вісник Львівського торговельно-економічного університету. Економічні науки. № 61, 2020

6. Kolot, A. M. (2008), Innovatsiyno-intelektual'ni chynnyky rozvytku vyshchoyi osvity yak providnoho instytutu ekonomiky znan', Stratehiya rozvytku Ukrayiny: ekonomika, sotsiolohiya, pravo, vyp. 1-2, NAU, K., s. 502-507.

7. Kravchenko, O. O. and Kykot', S. V. (2016), Psykholohichni aspekty upravlinnya personalom, $\mathrm{Mo}$ lodyy vchenyy, № 3, s. 101-103.

8. Rudenko, M. V. (2016), Navchannya personalu yak resursna skladova upravlinnya pidpryyemstvom, Visnyk Khmel'nyts'koho natsional'noho universytetu. Ekonomichni nauky., Khmel'nyts'kyy natsional'nyy universytet, Khmel'nyts'kyy, № 2, T. 1, s. 33-38, available at : http://journals.khnu.km.ua/vestnik/pdf/ ekon/pdfbase/2016/ VKNU-ES-2016-N2Volume1_234.pdf\#page=33.
9. Statsenko, Ye. V. and Loboda, Yu. V. (2011), Adaptatsiya mizhnarodnykh nematerial'nykh metodiv motyvatsiyi personalu do suchasnoyi systemy stymulyuvannya pratsi v Ukrayini, Ekonomika ta upravlinnya, c. 11-13.

10. Teoriya priobretennykh potrebnostey D. MakKlelanda, Entsiklopediya menedzhmenta (2013), available at: http://www.pragmatist.ru/motivaciyatruda/teoriyapriobretennyx-potrebnostej-d-

makklellanda.html.

11. https://dspace.nuph.edu.ua/bitstream/ $123456789 / 10824 / 1 /$.

12. http://vlp.com.ua/files/84_0.pdf.

Стаття надійшла до редакиії 18 жовтня $2020 \mathrm{p}$. 